\title{
Konflik Antar-tokoh dan Antar-agama dalam Novel Keluarga Permana karya Ramadhan K.H
}

\author{
R. Myrna Nur Sakinah \\ myrnanursakinah@yahoo.com
}

\begin{abstract}
ABSTRAK
Penelitian ini membahas tentang konflik antar tokoh dan agama pada novel Keluarga Permana karya Ramadhan K.H. Karya ini memiliki kekuatan dalam mengungkap ideologi seseorang dalam sebuah keluarga. Terkait dengan ideologi, karya ini dipengaruhi oleh struktur sosiologi masyarakat yang dilatarbelakangi oleh perbedaan keyakinan. Penelitian ini membahas kajian sosiologi sastra. Dari hasil analisis penelitian ini ditemukan bahwa ideologi seseorang menimbulkan beberapa konflik antar tokoh dan agama.
\end{abstract}

Kata kunci: ideologi, konflik, karakterisasi, dan representasi

\begin{abstract}
This research discusses about conflict between the actors and the religion on Keluarga Permana's novel. This text have strength to find of someone's ideology in a family. Based on ideology, this text can be influenced by sosiological of society which of the different background. This research disscuss about sosiology of literature. From this analysis be found that someone's ideology appear of conflict between the actors and the religions.
\end{abstract}

Keywords: ideology, conflict, characterization, and representation

1. Latar Belakang Masalah

Keluarga Permana adalah novel

karya Ramadhan K.H yang merepresentasikan kehidupan keluarga sederhana. Berawal dari kisah tokoh kepala keluarga yang bernama Permana mengalami posisi yang teralienasi dari tempat ia bekerja sehingga harus mengalami pengangguran dalam hidupnya. Alhasil, kondisi kejiwaannya terancam menjadi seseorang yang pendiam, pemuram, dan pemarah. Keadaan yang menurutnya serbasalah itu menyebabkan rumah tanggnya mengalami konflik, pertengkaran, dan ketegangan bersama dengan istrinya, Saleha, dan anak perempuannya,Farida.

Beberapa permasalahan kecil selalu dianggapnya menjadi permasalahan besar sehingga menyebabkan Permana menjadi seorang yang bengis dengan berbuat semenamena terhadap istri dan anak perempuannya, yakni terjadi kekerasan dalam rumah tangga. Tetapi Permana tidak selalu menjadi akar permasalahan dalam keluarga itu, tetapi istrinya Saleha. Hal lain yang mendorong Permana menjadi seseorang yang kejam karena dilanda rasa cemburu yang berlebih terhadap istrinya yang diantar pulang oleh pimpinannya yang berkerja hingga senja. Terlalu banyak konflik yang terjadi di dalam keluarga itu sehingga membuat suasana keluarga menjadi dingin dan hampa.

Pada suatu hari datanglah Sumarto, seorang pemuda dari 
Jatiwangi, yang memiliki tujuan pergi ke Bandung untuk bekerja dan kuliah. Ia berkeyakinan Kristen Katolik. Ia mendatangi rumah keluarga Permana yang sangat sederhana itu guna menyewa salah satu kamar untuk dijadikan tempat tinggal baginya. Hal ini diterima Permana demi mendapatkan uang sampingan dengan menyewa kamar yang dapat dimanfaatkan oleh pemuda itu.

Pada suatu saat Ida mengenali pemuda itu dan dengan mudah mereka bergaul sangat akrab. Dengan hadirnya Sumarto di dalam keluarga itu, kini Ida berkelakuan tidak wajar, yakni memanfaatkan waktu sempit untuk dapat menghubungi Sumarto, baik di dalam kamarnya maupun di tempattempat lain. Hubungan diam-diam antara Sumarto dan Ida semakin dekat dan tidak terkendali sehingga Ida dengan mudah untuk memasrahkan keperawanannya kepada Sumarto. Hal ini tidak disesali oleh Ida karena ia memiliki perasaan cinta yang berlebih terhadap Sumarto. Hal ini diperhatikan oleh Komariah, seorang pembantu keluarga Permana, ia lebih sering untuk tinggal di rumah. Lambat laut kedekatan mereka ini terdengar di telinga Saleha dan akhirnya mendarat di telinga Permana. Permana mencari cara agar Sumarto dapat melangkahkan kaki di rumah itu. Akhirnya, caranya ini berhasil membuat pemuda itu pergi.

Semakin hari Ida merasa kesepian tanpa hadirnya Sumarto sehingga akhirnya ia merasakan sesuatu, rasa sakit pada tubuhnya yang kecil itu. Ida merasa pusing dan mual berlebih. Setelah diketahui bahwa Ida mengalami kehamilan, Permana dan Saleha mencoba merahasiakan perihal ini dari orang lain dan mencari cara agar kandungan Ida dapat digugurkan. Menurut ajaran agama tertentu, hal ini adalah hal yang dilarang, melakukan seks sebelum tiba waktunya (Marriage before Action) karena dianggap sebagai sebuah aib yang sangat besar di dalam keluarga.

Pada suatu saat Saleha pergi menghadapi seorang dukun yang dipercayainya memiliki kesaktian. Dengan cairan yang diberikan dukun itu, akhirnya Saleha memaksa Ida untuk meminumnya agar kandungannya dapat mati. Setelahnya, kesehatan Ida semakin terancam dan akhirnya Ida dibawa ke rumah sakit untuk melakukan operasi pada tubuhnya yang disebabkan oleh cairan yang diberikan dukun itu. Orang tuanya merasa sangat menyesali atas perbuatannya yang memaksa Ida untuk melakukan pengguguran kehamilannya. Kabar ini akhirnya terdengar di telinga Sumarto. Sumarto merasa sangat menyesal atas apa yang telah diperbuatnya terhadap Ida. Kemudian Sumarto mengirimkan sesuatu berupa surat kaleng tertuju kepada orang tuanya yang isinya menyatakan bahwa pengguguran adalah pembunuhan. Namun, surat ini tidak sampai ke tangan Permana. Ida merasa getir setelah mengetahui isi surat itu.

Setelah Ida pulih dari sakitnya dan keluar dari rumah sakit, Sumarto meyakinkan bahwa ia tetap mencintai Ida dan tetap akan bertanggung jawab atas perbuatan yang telah dilakukannya. Begitu pula Ida, ia merasa bahwa hanya Sumartolah satu-satunya laki-laki yang ia cintai, tempat menumpahkan kepercayaan dan isi hatinya. Ida merasa tidak ada pemuda lain yang dapat menerimanya, kecuali Sumarto. Lebihlebih Ida merasa bahwa hidupnya telah ternodai sehingga ia merasa lebih baik jika dapat hidup selamanya bersama Sumarto walaupun mereka berpegang pada keyakinan yang berbeda. Dalam posisi ini, kepercayaan keyakinan Idalah yang runtuh sehingga ia harus berpindah keyakinan. Hal ini masih 
bergolak karena sebenarnya Ida merasa bahwa keyakinannya tidak dapat di rubah dengan mudah. Namun, hal itu terpaksa Ida lakukan demi kehidupannya bersama Sumarto walaupun sebenarnya sulit untuk diterimanya.

Pada akhirnya, orang tua Ida pun memasrahkan apa yang dikehendaki Ida, yaitu mengikuti keyakinan Sumarto yang akan menjadi suaminya. Ida melangsungkan pernikahan dengan Sumarto melalui catatan sipil dan melalui gereja. Meskipun banyak pihak keluarga dari Ida yang tidak menyetujui pernikahan ini, akhirnya Ida pun dapat menjadi Nyonya Sumarto seutuhnya. Setelah acara pernikahan itu, mereka berangkat ke Jatiwangi untuk menjalani kehidupan baru tinggal bersama orang tua Sumarto, yaitu Sutomo dan Sutarmi.

Seminggu setelah pernikahan, Ida jatuh sakit karena luka yang dideritanya masih membekas. Akhirnya, Ida pun dibawa ke rumah sakit untuk melakukan perawatan. Namun, sayangnya kesempatan Ida untuk hidup lebih lama bersama Sumarto hanyalah sebuah impian. Ida meninggal dunia dan dibawa pulang ke pelukan keluarga Permana agar dapat dikuburkan di tanah kelahirannya. Permana merasa sangat terpukul dengan kepergian anak kesayangannya di dunia ini. Sebelum kematian Ida, Keluarganya berharap agar Ida tetap berada dalam keyakinannya walaupun secara kenyataannya tidak.

Konflik yang kerapkali terjadi dalam novel Keluarga Permana ini merupakan konflik yang sering kita temui dalam masyarakat Indonesia. Menurut Rosidi (2000:89) Keluarga Permana adalah salah satu karya penting di Indonesia, mungkin sama pentingnya dengan Atheis yang telah menggoncangkan masyarakat sekitar tahun 1950. Ramadhan telah membawa warna daerah masuk ke dalam novelnovelnya sehingga memberikan nuansa baru dalam memperkaya kesusastraan Indonesia. Dalam hal ini karya sastra dapat dimanfaatkan untuk menyampaikan segala pesan dan tujuan, baik politik, ekonomi, kebudayaan maupun sosial itu sendiri.

Berdasarkan uraian di atas, karya sastra yang memanfaatkan ideologi menjadi hal yang penting untuk dilakukan karena hal ini erat kaitannya dengan kehidupan sosial seseorang. Dalam hal ini peneliti akan menganalisis bentuk konflik yang terjadi baik antartokoh ataupun antaragama.

\section{Kepengarangan dan Kedudukan Ramadhan K.H dalam Kesusastraan Indonesia \\ Ramadhan K.H adalah nama} singkat dari Haji Ramadhan Kartahadimadja. Ia lahir di Kota Priangan, Bandung pada tanggal 16 Maret 1927 dan wafat tepat pada tanggal kelahirannya, 16 Maret 2006 di Cape Town, Afrika Selatan. Ia tumbuh besar di daerah Cianjur. Ramadhan K.H adalah salah satu sastrawan besar Indonesia yang karya-karyanya dijadikan sebagai rujukan dari pengembangan karya sastra Indonesia sampai masa kini. Ia mulai belajar menulis pada Zaman Jepang atas dorongan kakaknya Ach. K. Hadimadja. Kepiawaiannya dalam bidang menulis membawa ia menjadi seorang penyair, novelis, penerjemah, redaktur kebudayaan, dan seorang wartawan olahraga. Pekerjaan menjadi seorang wartawan olahraga ini telah membawanya berkesempatan "go international" untuk merekam olimpiade di Helsinki (1952) ${ }^{1}$.

\footnotetext{
${ }^{1}$ Menurut (HB Jassin, 1976, Ajib Rosidi, 1976, 2000, Jakob Sumardjo, 1983; A Teeuw, 1989), Pekerjaan ini memberi kesempatan padanya
} 
Disebutkan bahwa pengalamannya dalam bekerja pada kantor Antara selama 13 tahun telah membantunya untuk menjadi seorang wartawan pada beberapa majalah, di antaranya: Kisah, Siasat, Siasat Baru, Kompas, dan Budaya Jaya. Selama hidupnya, ia pernah ditahan selama 16 hari di Kamp Kebon Waru, Bandung, bersama-sama dengan Dajat Hardjakusumah ${ }^{2}$. Keduanya ditahan karena merupakan korban fitnah dan dianggap sebagai pendukung dari G30 S/PKI.

Ramadhan K.H. merupakan penulis besar Indonesia yang tergolong penulis era tahun 1950-1960. Laelasari dan Nurlaelasari (2007:357) menyatakan bahwa pada tahun 1953, Ramadhan K.H mempelajari bahasa dan kesusastraan Spanyol sehingga berhasil menerjemahkan karya Federico Garcia Lorca yang berjudul Rumah Bernarda Alba, Romansa Kaum Gitana, dan Yerma. Hal ini menandakan bahwa Ramadhan K.H layak menjadi seorang sastrawan besar di Indonesia karena ia telah berpikir kritis terhadap kesusatraan Indonesia.

Karya-karya Ramadhan K.H cukup banyak meliputi puisi, esai, biografi dan roman. Adapun puisi pertama yang menjadi karyanya adalah Priangan Si Jelita, memperoleh hadian BMKN (Badan Musyawarah Kebudayaan Nasional) pada tahun (1957-1958), menurut Damono (2012), menilai buku tersebut sebagai puncak prestasi Ramadhan di dunia sastra Indonesia karena buku itu adalah salah

untuk merekam kegiatan-kegiatan olah raga internasional di luar negeri, antara lain di India dan menghadiri Olympiade 1952 di Helsinki. Pengalaman-pengalaman ini, di antaranya menjadi bahan salah satu novel yang di tulisnya, begitu pula perlawatannya ke Eropah dan pemukiman di Spanyol tahun 1953.

${ }^{2}$ Ayah kelompok pemusik Bimbo yang saat itu menjadi pimpinan kantor Antara cabang Bandung di tahun 1965 satu buku kumpulan puisi terbaik yang pernah diterbitkan di Indonesia, biografi Inggit Genasih Kuantar ke Gerbang (1981), Soeharto: Pikiran, Ucapan dan Tindakan Saya (1998), Gelombang hidupku: Dewi Dja dari Dardanella (1982), roman yang berjudul Royan Revolusi $^{3}$ (1968) memperoleh hadiah untuk sayembara roman yang diselenggarakan oleh IKAPI, roman Kemelut Hidup dan Keluarga Permana (1964) memenangkan hadiah penulisan dari DKJ (Dewan Kesenian Jakarta), Ladang Perminus (1990), serta karyakarya lainnya.

Novel Keluarga Permana (1978) merupakan novel yang bertema tentang perkawinan campuran Kristen-Islam dan ketegangan-ketegangan yang timbul dalam masyarakat Islam tradisional. Kemudian disebutkan bahwa pengungkapan konflik keagamaan seperti yang melanda keluarga Islam tersebut menjadi suatu sumbangan penting bagi sastra Indonesia modern yang pada waktu itu tidak menjadi tolak ukur dalam karya sastra.

\section{Rumusan Masalah}

Berdasarkan latar belakang di atas bahwa penelitian ini akan membahas dua permasalahan yang terjadi, konflik sosial dan konflik keagamaan.

1) Bagaimana bentuk konflik antartokoh yang terjadi dalam novel Keluarga Permana karya Ramadhan K.H?

2) Bagaimana bentuk konflik antaragama yang terjadi dalam novel Keluarga Permana karya Ramdhan K.H?

\section{Tujuan Penelitian}

Adapun tujuan permasalahan yang dirumuskan adalah untuk menjawab

\footnotetext{
${ }^{3}$ Merupakan roman yang diterjemahkan ke dalam bahasa Perancis.
} 
identifikasi rumusan masalah di atas, yaitu:

1) Menemukan konflik antartokoh yang terjadi dalam novel Keluarga Permana karya Ramadhan K.H.

2) Menemukan konflik antaragama yang terjadi dalam novel Keluarga Permana karya Ramdhan K.H.

\section{Sumber Data}

Adapun sumber data dalam penelitian ini adalah novel karya Ramadhan K.H ini, yang berjudul:

Keluarga Permana yang diterbitkan oleh PT Dunia Pustaka Jaya , Jakarta Pusat, tahun 1986, cetakan kedua; cetakan pertama diterbitkan pada tahun (1978) oleh penerbit yang sama, PT Dunia Pustaka Jaya, Jakarta Pusat.

\section{Konflik Sosial dan Agama dalam Kritik Sastra}

Sasaran yang akan dituju dalam hal ini adalah penelitian tentang sosiologi sastra. Menurut Endraswara (2008:78),"Sosiologi sastra adalah pantulan dari konsep cermin (mirror). Dalam kaitan ini karya sastra dianggap sebagai mimesis (tiruan) masyarakat." Dengan kata lain, sosiologi sastra merupakan refleksi dari kehidupan seseorang terhadap kehidupan sosial yang variatif. Menurut Damono (1978:6), "Sosiologi sastra adalah telaah yang objektif dan ilmiah tentang manusia dalam masyarakat; telaah tentang lembaga dan proses sosial." Secara esensial, sosiologi sastra merupakan penelitian tentang studi ilmiah manusia dan masyarakat secara objektif dalam mencakup segala hal yang berkaitan dengan komunikasi masyarakat. Kehidupan yang variatif mengakibatkan gejala-gejala tertentu dalam refleksi sosial masyarakat, di antaranya dunia sosial dan sekelilingnya, individu terhadap sosial maupun politik, adanya hubungan sastra dan politik, dan konflik-konflik yang membuat ketegangan baik secara individual maupun non individual.

Menurut Hardjana (1994:83) dalam menanggapi pandangan tentang keagamaan adalah kemampuan untuk mengingkari diri, pandangan-pandangan tentang keagamaan tautannya disingkirkan untuk sementara agar dapat pengertian wajar (objective sympathy) menemukan kembali apa yang sebenarnya diungkapkan pengarang. Seorang pembaca atau kritikus sastra secara kondisional harus dapat menyeimbangkan kedudukan agama dalam karya sastra agar tidak terjadi ketumpangtindihan dalam pengaruh eksistensi karya sastra.

Adapun penelitian yang akan dituju dalam hal ini adalah konflik antar tokoh dan keagaamaan yang terjadi, baik itu secara individu maupun sosial. Menurut Saini KM dalam Endraswara (1986:14-15), ada tiga kedudukan sastra terhadap kehidupan masyarakat, yaitu sebagai pemekatan, penentangan, dan olok-olok. Ketiga fungsi ini merupakan fungsi sastra bagi kehidupan sosial yang akan berkembang berdasarkan pandangan, sikap, dan nilai-nilai termasuk kebutuhan seseorang serta norma yang berlaku.

\section{Konflik Antartokoh dan Antaragama}

Konflik dalam karya sastra kerapkali selalu hadir. Keberadaan konflik dalam karya sastra memengaruhi khazanah penceritaan dalam sebuah cerita. Konflik merupakan bumbu dari sebuah penceritaan. Menurut Klarer (1998:15), "Konflik (complication or conflict) adalah situasi awal yang dihadirkan menuju titik puncak (climax) dalam sebuah pengolahan produksi penceritaan." Kehadiran konflik dalam sebuah karya sastra sangat berpengaruh dalam pencitraan cerita. Kokoh dan 
tidaknya suatu karya sastra bergantung pada konflik yang dihadirkan oleh pengarang dalam karya tersebut. Boal (1985:38) menyebut konflik (conflict) dengan sebutan 'hamartia', 'bahwa tokoh dalam penceritaan mengalami kecacatan $(\sin )$. ." Artinya, tokoh dalam karya mengalami "kerusakan atau kebinasaan" pada karakter-karakternya sehingga keberadaannya berpengaruh terhadap kehidupan sosial.

Konflik yang terjadi dalam karya ini kerapkali timbul dari tokoh Permana, kepala keluarga, karena dirinya yang didapati sebagai seseorang yang mengalami pengangguran. Konflik lain timbul dari tokoh-tokoh lain seperti istrinya, Saleha, dan anak perempuannya, Ida. Perbedaan keyakinan Kristen dan Islam antara Sutomo dan Ida menimbulkan konflik besar di antara dua keluarga. Konflik yang terjadi kerap timbul di sekitar kita sehingga dalam menganalisis karya ini ditemukan beberapa konflik yang terjadi, baik itu konflik antartokoh maupun konflik antaragama.

\section{a. Konflik Antartokoh}

Konflik antartokoh merupakan salah satu pemicu dari mengalirnya karya sastra yang dibuat oleh pengarang. Dengan membaca konflik tokoh dalam karya ini, peneliti menemukan kenikmatan dalam berimajinasi. Adapun konflik antar tokoh dibagi ke dalam dua bagian karena terdapat dua situasi yang berbeda yakni di dalam dan di luar keluarga.

\section{1) Konflik Antartokoh dalam Keluarga}

Konflik dalam sebuah keluarga kerapkali muncul sebagai bumbu dalam kehidupan berumah tangga. Hal ini pun didapati dalam keluarga Permana, konflik antaranggota dalam keluarga menimbulkan kekerasan yang akhirnya munculah keributan yang tidak menentu. Seorang istri, lebih cenderung bersifat feminin karena rasa ketakutan yang dimilikinya lebih besar dari pada keberanian. Kedudukan istri menjadi tersubordinasi dari kekuasaan seorang suami yang dilanda kemarahan. Menurut Sugihastuti (2010:88) terjadinya subordinasi terhadap perempuan disebabkan oleh tidak adanya rasa pengertian laki-laki terhadap perempuan. Tersubordinasinya tokoh Saleha di mata Permana membuat Saleha menjadi seseorang yang dengan mudahnya disiksa dan dihina.

Waktu ibu Ida pergi menjauhi kemungkinan yang lebih parah, ketakutan, ayah Ida tinggal sendirian. Ia diam di kamar tak menentu. Ini bukan keributan yang pertama kali, tapi Ida kali ini gelisah benar melihat kejadian itu di balik jendela kamar. Kasihan melihat ibunya disiksa, dihina dengan begitu rendah (Ramadhan K.H, 1986:24)

Dalam psikologi pendidikan anak, pengaruh pendidikan dan pergaulan orang tua menentukan faktor penunjang masa depan anak. Faktor kekerasan dalam rumah tangga merupakan suatu hal yang harus dihindari di mata anak karena secara tidak langsung kejadian kekerasan akan terus terekam semasa hidupnya. Konflik yang terus bermunculan di keluarga Permana berimbas kepada anak perempuannya, Ida, sehingga tokoh Ida seringkali dipertemukan dengan kekerasan fisik yang dilakukan oleh ayahnya, Permana. Kekerasan fisik yang dilakukan oleh ayahnya secara tidak langsung akan terus terekam dalam pengalaman Ida. Praktik pengancaman yang dilakukan Permana akan membuat sel otak anak dalam pembentukan kepribadiannya menjadi terganggu. Oleh karenanya, konflik praktek kekerasan dan pengancaman 
berlebih yang dilakukan permana membuat Ida mengalami ketakutan untuk berhadapan dengannya. Cara lain yang dilakukan Ida untuk menghindari kekejaman ayahnya adalah dengan melarikan diri dari hadapannya.

Rotan melayang dengan seketika, mencambuk tangan Ida. Lalu mencambuk kakinya. Sebelah kiri. Lalu yang sebelah kanan. Dengan tak ada belas kasihan sedikit pun. Ida lari dari kamarnya. Dan masih mengiang di telinganya kata-kata ayahnya yang mengancam, "Ayo, laporkan seтиa ini pada ibumu! Dan awas kau tak segera melaporkan padaku di mana ibumu. Cari cepat di mana dia. Cari!" (Ramadhan K.H., 1986:25)

Konsep stereotipe pada perempuan dan laki-laki menunjukkan dua kutub berlawanan. Perempuan lebih cenderung memiliki sifat lembut, cantik, emosional dan keibuan. Sementara itu, laki-laki lebih cenderung bersifat kuat, gagah, dan perkasa. Ini menandakan bahwa perempuan lebih cenderung bersifat feminin, sedangkan laki-laki bersifat maskulin. Kedudukan laki-laki yang bersifat maskulin membawa Permana menjadi sosok yang penuh dengan kekerasan. Permana menunjukkan sebuah sikap yang menimbulkan konflik atas segala kekuasaanya sebagai seorang suami. Ideologi yang dimiliki oleh Permana cenderung bersikap kukuh dan keras sehingga keegoisannya untuk tidak mendengarkan orang lain membuat orang lain menjadi korban dari sikapnya. Perlakuannya yang kukuh dan keras menyebabkan Saleha menjadi objek pelampiasannya.

Dalam pada itu Saleha sudah merasa terluka. Ia merasa dihina. Ia merasa nasibnya begini jelek di hari-hari belakangan ini. Ia sudah ditempeleng, ditendang, dipukuli dan sekarang dicurigai main-main dengan laki-laki lain. (Ramadhan K.H., 1986:36)

Pendirian Permana sebagai seseorang kepala keluarga bersikap tegas dan berani terhadap istri dan anakanaknya. Dalam hal ini, Tidak ada orang tua yang ingin menjerumuskan anaknya ke jurang yang salah. Begitu pula dengan Permana, watak keras yang dimilikinya tidak serta merta membawa anaknya untuk terjun ke dalam jalan yang salah. Sebagai orang tua yang wajar, Permana menginginkan anaknya dapat memiliki sikap yang anggun, tegas, dan berwibawa terhadap dirinya. Ini terlihat ketika Permana mengingatkan anak perempuannya yang mengalami masa keremajaan. Hanya saja penyampaiaan kasih sayang yang disampaikan Permana lebih terkesan dengan cara membentak. Alhasil, ia terlihat seperti seorang bapak yang keras.

Aku tidak setuju kamu berlaku begitu. Cekikikan kaya perempauan murah. Apa itu! Kamu tidak boleh lagi masuk di kamar itu. Mengerti? "'(Ramadhan. K.H., 1986:59)

Konflik lain yang terjadi dalam Keluarga Permana ditimbulkan oleh tokoh Permana yang memberikan peluang bagi orang lain untuk masuk ke dalam keluarganya karena demi mendapatkan sebuah penghargaan di mata sang istri menutupi rasa "kegengsian" dalam dirinya. Beranjak dari permasalahan ini, akhirnya Permana dan Saleha mencurigai segala perbuatan yang dilakukan oleh anak perempuannya, Ida, dengan laki-laki pendatang itu, Sumarto. Kedatangan Sumarto dalam keluarga Permana menjadi sebuah momok keras di antara Permana dan Saleha. Terbukti bahwa anak perempuannya yang menuju dewasa ini diduga mengalami 
kehamilan karena ia mendapati ciri-ciri dari proses terjadinya kehamilan, yakni mual, muntah dan tidak mengalami fase haid selama dua bulan. Hal ini menjadi sebuah persoalan besar bagi Permana dan Saleha. Proses menjadi maskulin kerapkali ditemukan dalam diri perempuan. Adalah Saleha yang bekerja di luar sebagai tulang punggung dari keluarga. Saleha mempermasalahkan keyakinannya bahwa seharusnya sebagai seorang suami, Permana dapat mempercayai Saleha yang membanting tulang di luar arena keluarga.

"Ah kau selalu melihat ke belakang. Sekarang, yang kita hadapi adalah bagaimana seharusnya kita bertindak dan apa yang harus kita perbuat. Yang ke belakang jangan kau utik-utik lagi. Lagi pula siapa yang membuka pintu sampai kita kemasukan si Toto? Beginilah jadinya, kalau amu tidak percaya sedikit pun pada kekuatan perempuan, seperti perempuan tidak akan mampu memberi hidup pada yang ada di rumah. (Ramadhan K.H., 1986:81)

Persoalan lain yang timbul adalah berawal dari keberadaan Sumarto di dalam keluarga Permana. Semula Permana menganggap Sumarto sebagai pemuda yang ramah dan dapat bersosialisasi sewajarnya. Namun hal itu bertentangan dengan realita yang terjadi. Sebaliknya, Sumarto dengan sadar menjerumuskan Ida ke dalam jurang indah. Ini berarti Sumarto telah melakukan pelanggaran atas keluarga Permana karena dengan beraninya Sumarto membawa Ida demi memenuhi kepentingan nafsunya saja. Hal ini dinilai sebagai pelecehan bagi mereka. Permana dan Saleha merasa tersinggung atas sikap yang dilakukan oleh Sumarto sehingga hal ini menjadi sebuah konflik bagi mereka.
Kamu tidak mengerti? Ia sudah menghina kita. Ia menganggap kita tak lebih dari sampah. Coba ingat. Dia kita tolong tinggal di sini. Benar, waktu itu aku yang menolong. $\quad A k u \quad y a n g$ mengizinkannya tinggal di sini. Aku kira waktu itu dia cukup sopan. Nyatanya dia menjerumuskan anak kita, dan dia seret kita ke dalam penghinaan macam ini. (Ramadhan K.H., 1986:84)

Persoalan-persoalan di atas ini merupakan titik permasalahan yang terjadi di dalam keluarga Permana sehingga hal-hal yang bersangkutan dinilai sebagai konflik yang terjadi dalam sebuah keluarga.

\section{2) Konflik Antartokoh di Luar Keluarga}

Konflik antartokoh di luar keluarga adalah konflik yang terjadi bersama dengan anggota non keluarga. Dalam kehidupan sosial masyarakat, individu seseorang tidak akan terlepas dari pengaruh orang lain. Selama manusia itu hidup berarti selama itu pula ia memiliki hubungan dengan orang lain. Tokoh Nenek Tati yang telah dianggap nenek kandungnya sendiri oleh Ida merupakan tempat peraduan tatkala Ida merasakan pedih luka pukulan dari ayahnya. Ida yang telah melarikan diri dari rumah menuju rumah Nenek Tati karena merasa takut oleh siksaan ayahnya membawa pengaruh besar terhadap orang lain sehingga ini menjadi sebuah konflik permasalahan keluarga yang dibawa Ida ke luar ranah keluarga. Sekeras apapun seorang ayah tidak sampai hati membunuh anak perempuannya. Namun, posisi Ida dalam hal ini adalah posisi anak yang tidak bisa menahan permasalahan dalam keluarga sehingga isu permasalahan hinggap di telinga Nenek Tati. 
"Dengan terpatah-patah Ida menceritakan pengalamannya yang baru saja terjadi. Dia dipukuli ayahnya, dicambuk dengan rotan panjang yang sudah biasa tersedia di atas lemari pakaian. Sebelum itu ayahnya telah memukuli dan menendang ibu, Ida yang kemudian lari entah ke mana." (Ramadhan K.H., 1986:23)

Status sebagai seorang kepala keluarga disoroti dari berbagai sudut mata masyarakat. Status adalah menentukan posisi kedudukan seseorang di mata masyarakat umumnya. Menurut Linton (1984:148), "Status mewakili posisi setiap individu dalam berhubungan dengan masyarakat sebagai suatu keseluruhan." Permana merasa kehilangan statusnya sebagai kepala keluarga karena mengalami pengangguran dari pekerjaan yang selama ini ditekuninya.

Berkomunikasi dengan orang lain demi mendapatkan jalan keluar adalah hal yang baik. Begitu pula hal yang telah dilakukan oleh Saleha dalam menanggapi suaminya yang berlaku keras itu dengan cara mendiskusikannya kepada orang lain, Bi Tati. Namun sayang sekali, perbincangan antar kedua tokoh tersebut tidak dapat menyelesaikan permasalahan. Realitanya, Saleha secara tidak langsung telah memberikan coretan hitam bagi suaminya dengan bercerita kekerasan yang telah dilakukan oleh Permana. Kekerasan yang dilakukan Permana merupakan ciri khas yang barangkali ingin ditampilkan oleh pengarang untuk menggambarkan keadaan kehidupan masyarakat yang keadaan ekonominya berada di garis menengah ke bawah. Kehilangan sebuah pekerjaan adalah pemikiran yang berat bagi seorang kepala keluarga apalagi jika sampai ia mengalami sebuah pengangguran. Seolah-olah ia kehilangan wibawa di hadapan istri dan anaknya. Pengangguran adalah satu kata yang dapat mematikan kedudukan lakilaki di dalam berumah tangga. Hal ini terjadi pada tokoh Permana yang mengalami perubahan karakter menjadi seorang pemarah sehingga ia tidak percaya terhadap pekerjaan di mana pun yang menurutnya tidak adil, ia merasa tersisihkan (dibohongi) oleh pekerjaan yang selama ini menurutnya adalah sebagai batu pijakan. Ia merasa ketakutan hal itu akan terjadi lagi. Seharusnya tugas seorang istri tidaklah membicarakan keburukan-keburukan yang dimiliki oleh suaminya terhadap orang lain. Sebaliknya seorang istri seharusnya dapat menutupi keburukan suaminya dan sebaliknya.

Mencari pekerjaan di luar, dia tidak mau lagi. Dia merasa ketakutan. Dia katakan, ketidakadilan sudah meranjah ke mana-mana. Dia merasa terpukul sekali oleh pengalamannya di pabrik itu. Dia sudah kapok. (h. 29). Permana tidak menemukan keadilan. Ia merasa dikenakan keputusan yang jauh dari adil. Ia merasa dikambinghitamkan. Ia merasa bingung. (Ramadhan K.H., 1986:42)

Dalam tahap sosialisasi, manusia membutuhkan kehadiran orang lain sebagai perkembangan dalam berinteraksi sosial. Menurut Effendi dkk (2006:68) ada tiga tahap dalam sosialisasi, yaitu interaksi tahap keluarga, interaksi tahap orang-orang yang dianggap penting (significant others), dan interaksi tahap timbal-balik terhadap orang lain (generalized others). Jika seseorang telah memiliki ketiga tahap ini, dapat diartikan bahwa seseorang telah mampu untuk berinteraksi dengan siapapun orang yang ada dihadapannya. Biasanya, proses ini terjadi pada seseorang yang 
akan menghadapi masa kedewasaan, seperti tokoh Ida yang telah dengan cermat menghadapi kejadian yang melintas di depan matanya. Kehadiran Sumarto sebagai orang lain (pada mulanya) merupakan gejala awal dari interaksi tahap tiga, generalized others, pada saat Ida mulai menanggapi kehadiran Sumarto dengan penuh rasa girang. Hal ini dinilai sebagai sebuah konflik dari luar yang masuk ke dalam keluarga Permana dengan hadirnya seorang pemuda yang bernama Sumarto itu.

Permana mulai jengkel. Kemarin ia menyaksikan dari balik pintu kaca Ida masuk ke kamar Sumarto. Ia lihat bagaimana kedua orang di sana nampak begitu akrab. Ia saksikan bagaimana Ida berebutan buku dengan Sumarto sambil tertawa kecil cekikikan. Ia merasa tidak enak, canggung, muak dan cemburu jadi satu. (Ramadhan K.H., 1986:59)

\section{b. Konflik Antaragama}

Keberadaan orang tua dalam kacamata agama merupakan orang yang harus dihormati oleh anak. Mitos cerita tentang Malin Kundang, seorang anak yang durhaka, terhadap ibunya menjadi momok masyarakat sehingga keberadaan seorang anak dalam agama harus menjadi seseorang yang patuh akan titah dari orang tua. Dalam permasalahan ini, seorang Ida yang merasa disalahkan karena kebohongan yang dibuat oleh ayahnya tidak serta merta membuat Ida mengungkap kebohongan yang telah dilakukan oleh ayahnya. Eksistensi Ida sebagai seorang anak yang berbakti terhadap ayahnya sangat besar dengan cara Ida dapat menahan konflik dengan ayahnya agar tidak muncul, namun tidak dengan konflik kekasihnya, Sumarto. Bagaimanapun posisi Ida yang merasa disalahkan itu tidak dapat membuat dirinya menjadi seseorang yang merasa nyaman. Artinya, Ida lebih baik tersalahkan dari pada wibawa orang tuanya hilang di mata Sumarto.

Ida merasa disalahkan. Ia tidak terima. Tapi untuk menyampaikan prasangkanya, bahwa ayahnya berusaha memisahkan mereka, ia merasa tidak patut. Bagaimanapun ia merasa tidak pantas menjelekjelekan ayahnya sendiri. Ia diam beberapa saat. (Ramadhan K.H., 1986:69)

Dalam konsep keagamaan, hamil di luar nikah merupakan aib besar di dalam keluarga karena pengaruhnya dapat menyebar dalam penurunan reputasi kedudukan baik orang tua ataupun anak yang mengalaminya di mata masyarakat. Menurut Prabasmoro (2007:89)," hamil adalah praktik sosial yang diletakkan dalam kerangka sosial. Kita harus hamil dengan benar untuk dapat hamil dengan berterima." Benar bahwa seorang perempuan harus hamil dalam garis yang wajar karena jika tidak wajar ia akan mendapatkan cemoohan atau ejekan dari mata masyarakat. Hal ini didapati Ida karena Ida telah hamil di luar kewajaran dan ini merupakan konflik besar dalam keluarga yang kaitannya di mata agama adalah berdosa. Menurut pandangan agama Islam, Ida telah melakukan zina ghairu muhsan, yaitu telah melakukan dosa, yakni perbuatan suami istri yang dilakukan sebelum waktunya. Ida telah melanggar pelanggaran dalam kacamata agama yang diyakininya, Islam.

Sudah berapa bulan?" tanyanya. "dua bulan lebih rasanya.bibi jadi takut. Dan itu . . . . Nen Ida muntah-muntah. Dan Bibi pernah saksikan Nen Ida dipeluk oleh Den Toto. Dipeluknya di tempat tidur." (Ramadhan K.H., 1986:73) 
Cinta telah membuat mata hati Ida menjadi buta. Rasa malu yang dideritanya tidak serta merta dapat menjadi kuat dalam mempertahankan keyakinannya sebagai seorang yang muslim. Ini menjadi konflik besar bagi orang tua Ida, terutama Ibunya, Saleha. Ida lebih baik menangguhkan keyakinan yang selama ini ia pegang demi hidup bersama laki-laki yang dicintainya. Hal ini menandakan bahwa Ida bukanlah sesosok muslim yang berpegang teguh terhadap agama yang diyakininya karena dengan mudahnya ia menangguhkan keyakinannya.

"Saya yang akan menyesuaikan". "Apa maksudmu?" tanya Saleha asambil mengangkat muka.

"Ya, saya yang akan menyesuaikan. Saya yang akan jadi Katolik," kata Ida dengan nada seperti segala akibat sudah ia pikirkan dengan matang. (h. 132) .... "Saya sudah di baptis, Mamah," kata Ida sambil menengadah, menatap mata ibunya. Lalu tangisnya membersit lagi (Ramadhan K.H., 1986:140)

Namun dalam pengertian lain, Ida membantah keyakinannya terhadap ajaran agama barunya, Katolik, karena dalam hatinya masih terbesit bahwa ia masih berkeyakinan terhadap agama lamanya, Islam. Hal ini menandakan bahwa Ida bukanlah seseorang yang konsisten dalam beragama. Realitanya, secara fisik ia Katolik, namun secara batin ia beragama Islam.

Sementara hatinya masih memihak kepada keyakinannya yang lama, kepada ajaran yang pernah diberikan oleh Nenek Lengkong sewaktu ia masih kecil sekalipun jauh dari mendalam. (Ramadhan K.H., 1986:139)

Perbedaan keyakinan antara Ida dan Sumarto merupakan hal yang harus dipikirkan secara mendalam. Tidaklah menjadi sesosok Ida yang secara fisik Katolik, namun secara batin Islam. Perbedaan keyakinan dalam bentuk pernikahan yang menjadikannya satu adalah hal pokok dalam menjalani bahtera kehidupan rumah tangga. Kakek Ida, Mang Ibrahim, menyayangkan Ida yang berpindah keyakinan dengan cara karena Ida memiliki cinta terhadap orang yang berlainan keagamaan. Mang Ibrahim lebih menyalahkan orang tua Ida karena menurutnya orang tua yang kuat adalah mereka yang tidak akan melepas anaknya dengan cara mudah dari cengkramannya. Hal ini pun menjadi konflik besar bagi Permana dan keluarganya.

"Aduh," sesal Mang Ibrahim, "cucuku lepas. Hilang dari lingkungan kita. Ini kesalahan orang tuanya, kesalahan orang tuanya." Hatinya pilu benar. Ia merasa kecurian sesuatu yang amat berharga, yang dibawa lari ke tempat yang pantang untuk ditengok. (Ramadhan K.H., 1986:145)

Dalam hal ini, barangkali Ramadhan sebagai pengarang ingin menampilkan sesuatu yang berbeda dalam karyanya dengan mengangkat tema pernikahan ala Katolik dalam wilayah Islam. Mang Ibrahim merasa kaget atas cara pernikahan yang dilakukan oleh Ida dan Sumarto karena pada dasarnya Mang Ibrahim mengetahui cucunya adalah seorang yang Islam. Praktik pernikahan yang dilakukan di rumah Permana merupakan praktik pernikahan yang tidak sewajarnya dalam ajaran Islam. Namun sebenarnya hal ini tidaklah menyalahi adat karena Ida kini telah menjadi anak Maria. Yang menjadi tolok ukur adalah keberadaan lingkungan yang tidak wajar, yaitu berada di rumah yang bernotabene Islam. 
"Tahu Anda, Pastor, kalau sampai terjadi yang serupa ini di kampung saya? Bisa-bisa rumah ini dilempari dengan batu." (Ramadhan K.H., 1986:147)

Persoalan yang terjadi dalam konflik antaragama terlihat kontradiksi, namun tidak sampai menimbulkan kericuhan yang besar. Dalam hal ini Ramadhan dengan piawai menyusun konflik antar agama tanpa harus ada sebuah pertengkaran yang hebat.

\section{Penutup}

Hasil penelitian konflik dalam novel Keluarga Permana karya Ramadhan K.H ini menimbulkan dua konflik. Konflik antartokoh dalam keluarga menimbulkan hubungan sebab akibat, yakni terlihat pada tokoh Ida yang menjadi perempuan sensitif dan agresif karena mendapatkan penyiksaan yang berlebih dari ayahnya, Permana. Konflik antar tokoh di luar keluarga pun menimbulkan hubungan causal (sebab akibat), yakni membuat tokoh Ida menjadi seseorang yang berpindah keyakinan disebabkan pengaruh dari luar dengan datangnya sosok pemuda yang bernama Sumarto. Adapun konflik antaragama menyebabkan sebagian orang-orang yang menyayangi Ida dan menyayangkan keputusan Ida yang berpindah keyakinan sehingga harus kehilangan keyakinan yang sudah sejak lama dimilikinya, Islam.

\section{Daftar Pustaka:}

Boal, Augusto. 1985. Theatre of The Oppressed. New York: Theatre Communications Group.

Damono, Sapardi Djoko. 1979. Sosiologi Sastra Sebuah pengantar Ringkas. Jakarta: Pusat Pembinaan dan Pengembangan Bahasa Departemen Pendidikan dan Kebudayaan.
Effendi. Drs. Ridwan, dkk. 2006. Ilmu Sosial Budaya dan Budaya Dasar. Jakarta: Kencana Prenada Media Group.

Endraswara, Suwardi. 2008. Metodologi Penelitian Sastra. Yogyakarta:MedPress.

Hardjana, Andre. 1994. Kritik Sastra Sebuah Pengantar. Jakarta: PT Gramedia Pustaka Utama.

K.H Ramadhan. 1986. Keluarga Permana. Jakarta: PT Dunia Pustaka Jaya.

Klarer, Mario. 1998. An Introduction to Literary Studies. London: Routledge.

Laelasari, S.S dan Nurlailah, S.S, 2007. Ensiklopedia Tokoh Sastra Indonesia. Bandung: Nuansa Aulia.

Linton, Prof. Dr. Ralph. 1984. The Study of Man. Bandung: Jemmars.

Prabasmoro, P. Aquarini. 2007. Kajian Budaya Feminis Tubuh, Sastra, dan Budaya Pop. Yogyakarta: Jalasutra.

Rosidi, Ajip, 2000. Ensiklopedia Sunda. Jakarta: Pustaka Jaya.

Saini, K.M. 1986. Protes Sosial dalam Sastra. Bandung: Angkasa.

Suharto, Sugihastuti. 2010. Kritik Sastra Feminis Teori dan Aplikasinya. Yogyakarta: Pustaka Pelajar. 